\title{
Determination LMWL Wonosobo Area by Using Nuclear Technology, Case Study: Hydrogeology Study for Aqua Danone CSR Program
}

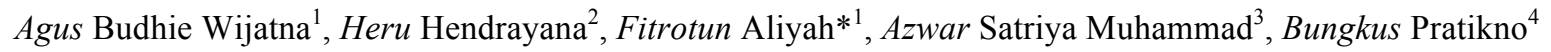 \\ ${ }^{1}$ Department of Nuclear Engineering and Engineering Physics, Universitas Gadjah Mada, Yogyakarta, Indonesia \\ ${ }^{2}$ Department of Geology Engineering, Universitas Gadjah Mada, Yogyakarta, Indonesia \\ ${ }^{3}$ PT Tirta Investama Danone Aqua, Jakarta, Indonesia \\ ${ }^{4}$ National Nuclear Energy Agency of Indonesia, Jakarta, Indonesia
}

\begin{abstract}
Corporate Social Responsibility (CSR) program is one of the management concepts whereby the company integrates social and environmental aspect to support their business as the strategy to achieve the company goals for balancing between economic, social, and environmental imperatives. PT Tirta Investama Danone Aqua, which located in Wonosobo has a core business in supplying natural drinking water. To fulfil its responsibility in conserving nature and groundwater reserves, PT Tirta Investama Danone Aqua has a CSR program called Aqua Lestari. The determination of the receiving area of the CSR program should review and analyzed in order the CSR programs is not misplaced. PT Tirta Investama wants the CSR program to be given to the groundwater recharge areas for maintaining groundwater reserves sustainability. Therefore, a comprehensive study concluded to determine the groundwater recharge area studied from the aspects of geology, hydrogeology, and hydro isotope. The application of nuclear technology especially for stable isotope tracer can be used to know the groundwater recharge area, and modeling the flow of subsurface groundwater. Local Meteoric Water Line (LMWL) is used for analysis of groundwater recharge area. The equation of LMWL Wonosobo is $\delta \mathrm{D}, \%$ o $=8,102 * \delta^{18} \mathrm{O}+$ $14,21 \%$.
\end{abstract}

\section{Introduction}

CSR or Corporate Social Responsibility is a corporate program which gives something to the beneficiaries in order to reach the balancing of economic aspect, social, and environment. PT Tirta Investama Danone Aqua, which located in Wonosobo, Central Java has a core business in supplying natural drinking water in the form of bottled water product. To fulfill its responsibility in conserving nature and groundwater reserves, PT Tirta Investama Danone Aqua has a CSR program called Aqua Lestari. The determination of the receiving area of the CSR program should be reviewed and analyzed in order the CSR programs is not misplaced. PT Tirta Investama wants the CSR program to be given to the groundwater recharge areas in order to maintain groundwater reserves sustainability. Therefore, a comprehensive study concluded to determine the groundwater recharge area studied from the aspects of geology, hydrogeology, and hydro isotope. Nuclear technology application through stable isotope analysis in groundwater compositions has proven useful as geochemical tools for exploration and management of groundwater resources [1]. The hydro isotope technology can measure the spring water of PT. Tirta Investama Danone Aqua comes from the groundwater recharge area which is obtained from a study of geology and hydrogeology.

\subsection{Site Description}

PT. Tirta Investama Danone Aqua has natural springs located in Wonosobo area, precisely in the mountains of Dieng plateau, Central Java, Indonesia. Most of the research areas are administratively located in Wonosobo District, Central Java Province. Astronomically, the study area is between the UTM coordinates Zone 49S lines 375400 - 390078 meters and 9186333 - 9203520 meters or $109^{\circ} 52^{\prime} 17$ "- $110^{\circ} 0^{\prime} 15^{\prime \prime}$ East Longitude and $7^{\circ} 12^{\prime} 16 "-7^{\circ} 21^{\prime} 35$ "south latitude of $251.55 \mathrm{~km}^{2}$ or about $25.6 \%$ of the total area of Wonosobo regency. The research area is also included in Temanggung Regency in the northeast and Banjarnegara District in the northwest.

Wonosobo regency is one of the city in Central Java with an area of $984.68 \mathrm{~km}^{2}$. It is located between $7^{\circ} 11$ 'and $7^{\circ} 36^{\prime}$ South Latitude, $109^{\circ} 43$ 'and 110 $4^{\circ}$ ' East

\footnotetext{
* Corresponding author: fitrotun.aliyah@mail.ugm.ac.id
} 
Longitude. The area mostly mountainous with a range from $250-2250$ meters above sea level (m.asl).

\subsection{Local Meteoric Water Line (LMWL)}

In hydrological cycle, the rainfall of precipitation will be a surface water or infiltrate to the ground and become groundwater resource. The surface water is susceptible to be evaporation which degree of evaporation will change the isotopic composition of surface water. On the other side, the infiltrated water is shielded by the reservoir rock from evaporation thus preserving the isotopic composition of the source rainwater. The groundwater consists of two types of circulating if the ground which are shallow groundwater and deeplycirculating groundwater. Shallow groundwater has the short circulating with near exit through locally-fed groundwater system. In another side, the deeplycirculating groundwater system has exit points in regionally-fed spring. The isotopic composition of the type (deeply circulating groundwater) is typically calculated using the rainwater data. The derived isotopic values, in term of Deuterium $\left({ }^{2} \mathrm{H}\right)$ and Oxygen-18 $\left({ }^{18} \mathrm{O}\right)$ are collectively called as the Meteoric Water Index (MWI) [1] or Meteoric Water Line [2]. Craig [3] first defined that the Global Meteoric Water Line (GMWL) used to $\delta^{2} \mathrm{H}=8 \delta^{18} \mathrm{O}+10$ an ordinary least squares regression. The primary source $\delta^{2} \mathrm{H}$ and $\delta^{18} \mathrm{O}$ data for GMWL is Global Network of Isotope in Precipitation (GNIP) globally [3]. For the local precipitation data is called Local Meteoric Water Line (LMWL).

Local Meteoric Water Line (LMWL) is a linear correlation of $\delta^{2} \mathrm{H}$ and $\delta^{18} \mathrm{O}$ contents which observed in the local area (Wonosobo precipitation). LMWL can be used to evaluate the origin of waters. For example: if the values of a pair of isotopes ratio determine from groundwater samples plot in the range of the Meteoric Water Line (MWL), it can be concluded that groundwater was recharged by local precipitations (originate from meteoric water).

Local Meteoric Water Line (LMWL) is often established from analysis of monthly rainwater samples in an area. The LMWL is used to a variety of hydrological application, commonly to determine the relationship of surface or groundwater to a potential precipitation source or to determine the degree of evaporation enrichment of the water [2].

The analysis of groundwater recharge area can't be separated from the calculation of LMWL because LMWL will be a basis whether the sample water is from rainwater/ surface water or groundwater.

The aims of the determination of LMWL equation is as a reference to know any hydraulic interconnection between groundwater samples from PT. Aqua Danone spring water and surrounding springs water. LMWL equation can be used as a reference in natural isotope research to study of groundwater dynamic in hydrology cycle and conduct mapping of groundwater recharge area.

\section{METHOD}

This study proposed that the samples examined were rainwater samples taken from different locations of elevation between Jembangan volcanoes, Dieng volcanoes, and Sundoro volcanoes. Samples of rain water were taken during the rainy season in five different locations with different elevations representing different characteristics of rainfall and the rainwater isotope fractionation process in the west slopes of the Sundoro volcano. Samples at different elevations are expected to know how the influence of elevation on changes in isotopic composition in rainwater. In each elevation were taken three times of sampling when high rainfall, medium rainfall, and low rainfall, so that the different effects of rainfall on isotopic compositions are easily observed.

Analysis of isotopic ${ }^{2} \mathrm{H} /{ }^{1} \mathrm{H}\left(\mathrm{D} /{ }^{1} \mathrm{H}\right)$ and ${ }^{18} \mathrm{O} /{ }^{16} \mathrm{O}$ isotope measurements were performed at the Earth and Environmental Laboratory, PATIR-BATAN, using a mass spectrometer. To minimize the occurrence of evaporation and contamination, the bottle cap of the sample is isolated by water tape insulation and fixing the time interval of the sampling to the laboratory analysis process no later than 5 days after sampling.

Measurement and analysis of the ${ }^{2} \mathrm{H} /{ }^{1} \mathrm{H}$ and ${ }^{18} \mathrm{O} /{ }^{16} \mathrm{O}$ isotope ratios are used to assess the effect of elevation and rainfall on the isotopic composition of the rainwater. Subsequently, the equations resulting from the study of the influence of elevation on the isotope composition $\left(\delta^{18} \mathrm{O}, \delta \mathrm{D}\right)$ of rainfall that falls on the West Slope of Sundoro volcanoes are called the Local Meteoric Water Line (LMWL)-Wonosobo equation. The origin of groundwater can be estimated from the equations formed on the influence of elevation on ${ }^{18} \mathrm{O}$ isotope ratio.

The value of $\mathrm{D} /{ }^{1} \mathrm{H}$ and ${ }^{18} \mathrm{O} /{ }^{16} \mathrm{O}$ isotope ratio from rain water samples is expressed relative to SMOW and written with the notation $(\delta \mathrm{D} \% \mathrm{o})$ and $\left(\delta^{18} \mathrm{O} \% \mathrm{o}\right)$ using equation $[4,5]$ :

$$
\begin{aligned}
& \delta=\frac{\text { Rsmpl }- \text { Rstd }}{\text { Rstd }} \times 1000 \% \\
& \delta D . \% \text { o }=\frac{\lfloor(D / H) \text { smpl }-(D / H) \text { smow }\rfloor}{(D / H) \text { smow }} x 1000 \ldots \ldots . . \\
& \delta^{18} O . \%=\frac{\left\lfloor\left({ }^{18} \mathrm{O} /{ }^{16} \mathrm{O}\right) \operatorname{smpl}-\left({ }^{18} \mathrm{O} /{ }^{16} \mathrm{O}\right) \text { smow }\right\rfloor}{\left({ }^{18} \mathrm{O} /{ }^{16} \mathrm{O}\right) \text { smow }} \times 1000
\end{aligned}
$$

$\%$

With;

$\mathrm{R}_{\text {smpl }}=$ isotope ratio $\left(\mathrm{D} /{ }^{1} \mathrm{H}\right.$ or $\left.{ }^{18} \mathrm{O} /{ }^{16} \mathrm{O}\right)$ of water sample

$\mathrm{R}_{\text {std }}=$ isotope ratio $\left(\mathrm{D} /{ }^{1} \mathrm{H}\right.$ or $\left.{ }^{18} \mathrm{O} /{ }^{16} \mathrm{O}\right)$ sea water

$\delta \quad=$ isotope ratio $\left(\mathrm{D}\right.$ or $\left.{ }^{18} \mathrm{O}\right)$ of water sample relative to the SMOW, \%o

$\delta \mathrm{D}=$ isotope ratio $\mathrm{D} /{ }^{1} \mathrm{H}$ water sample relative to SMOW, \%o 
$\delta^{18} \mathrm{O}=$ isotope ratio ${ }^{18} \mathrm{O} /{ }^{16} \mathrm{O}$ water sample relative to SMOW, \%

Standard mean ocean water (SMOW) is a standard for calibrating the composition of isotope ratio in the water sample. SMOW is from International Atomic Energy Agency (IAEA).

Based on the consideration that the largest of evaporation process occurs in the ocean, then the seawater is served as reference or SMOW. The isotope ratio of Deuterium $\left(\mathrm{D} /{ }^{1} \mathrm{H}\right)$ and Oksigen-18 standard $\left({ }^{18} \mathrm{O} /{ }^{16} \mathrm{O}\right)$ is 0.00015576 and 0.0020052 (Table. 1).

Based on this convention then most water (other than sea-water) has an isotope ratio $\delta \mathrm{D}$ and $\delta^{18} \mathrm{O}<0 \%$ (negative value) or based on Equations 2 and 3 above will apply [6]:

a) if $R_{\text {smpl }}>R_{\text {std }}$ then the value of $\delta_{\text {smpl }}>0$, means that the $\mathrm{D}$ or ${ }^{18} \mathrm{O}$ in the water sample is richer (enriched) than SMOW,

b) if $\mathrm{R}_{\text {smpl }}<\mathrm{R}_{\text {std }}$ then the value of $\delta_{\text {smpl }}<0$, means that the $\mathrm{D}$ or ${ }^{18} \mathrm{O}$ level in the water sample is poorer (depleted) than SMOW, and

c) if $\mathrm{R}_{\text {smpl }}=\mathrm{R}_{\text {std }}$, then $\delta_{\text {smpl }}=0$, means that the $\mathrm{D}$ or ${ }^{18} \mathrm{O}$ in water = SMOW or also can be interpreted that water sample comes from sea water.

Rainwater sample has the ratio of $\delta \mathrm{D}$ and $\delta^{18} \mathrm{O}$ depleted than ratio $\delta \mathrm{D}$ and $\delta^{18} \mathrm{O}$ of sea water due to the higher of elevation, the slower of temperature, vapor will be condensed again. Rainwater that falls on this higher elevation has a lower $\delta \mathrm{D}$ and $\delta^{18} \mathrm{O}$ isotope ratio. This phenomenon causes groundwater from higher elevation has $\delta \mathrm{D}$ and $\delta^{18} \mathrm{O}$ smaller than groundwater from the lower elevation.

Table 1. Isotope ratio of SMOW [6]

\begin{tabular}{|c|c|c|c|c|}
\hline & $\begin{array}{c}\text { Ratio, } \\
\mathrm{H} / \mathrm{L} \\
\left(=\mathrm{R}_{\text {std }}\right)\end{array}$ & $\mathrm{H} / \mathrm{L}$ & $\% \mathrm{H}$ & $\% \mathrm{~L}$ \\
\hline (1) & (2) & (3) & (4) & (5) \\
\hline Standar & $D^{\prime} H$ & 0.0001557 & 0.015574 & 99.98442 \\
\hline $\begin{array}{c}d \text { Mean } \\
\text { Ocean }\end{array}$ & ${ }^{17} \mathrm{O} /{ }^{16} \mathrm{O}$ & 0.0003799 & 0.0379 & 99.76206 \\
\hline $\begin{array}{c}\text { Water } \\
\text { (SMOW) }\end{array}$ & ${ }^{18} \mathrm{O} /{ }^{17} \mathrm{O}$ & 0.0020052 & 0.002005 & 99.76206 \\
\hline
\end{tabular}

Notes: $H=$ Heavy isotopes, and $L=$ Light isotopes

Besides the elevation influence, $\delta \mathrm{D}$ and $\delta^{18} \mathrm{O}$ value also depend on rainfall. The higher the rainfall, $\delta \mathrm{D}$ and $\delta^{18} \mathrm{O}$ ratio of rainwater are getting depleted and the lower the rainfall, the more enriched. Due to the rainfall, pressure and air temperature, and air humidity always fluctuated, so the value of $\delta \mathrm{D}$ and $\delta^{18} \mathrm{O}$ in every sample location should be calculated with this equation $[4,5]$ :

$$
\begin{aligned}
\delta^{18} O, \% o & =\frac{\sum_{i=1}^{n} P_{i} \delta_{i}{ }^{18} O}{\sum_{i=1}^{n} P_{i}} \\
\delta^{2} H, \% o & =\frac{\sum_{i=1}^{n} P_{i} \delta_{i} D}{\sum_{i=1}^{n} P_{i}}
\end{aligned}
$$

with:

$\delta^{18} \mathrm{O}=$ average isotope ratio ${ }^{18} \mathrm{O} /{ }^{16} \mathrm{O}$ relative to SMOW in rainwater, \%o

$\delta \mathrm{D}=$ average isotope ratio $\mathrm{D} /{ }^{1} \mathrm{H}$ relative to SMOW in rainwater, \%o $\delta_{\mathrm{i}}{ }^{18} \mathrm{O}=$ isotope ration ${ }^{18} \mathrm{O} /{ }^{16} \mathrm{O}$ relative to SMOW in rainfall to(i), \%o

$\delta_{\mathrm{i}} \mathrm{D}=$ isotope ration $\mathrm{D} /{ }^{1} \mathrm{H}$ relative to SMOW in rainwater to (i), \%o

$\mathrm{P}_{\mathrm{i}} \quad=$ amount of rainfall between the sample (i-1) to (i), mm per month

The value of $\delta \mathrm{D}$ and $\delta^{18} \mathrm{O}$ in some rainwater samples is linear and follow the equation 6 . The research showed that for un evaporated rainwater, the 6 depends on geographical factors, particularly with regard to temperature, humidity, thickness, and precipitation. From rainwater samples taken globally through 91 rainfed stations worldwide, $\mathrm{d}=10$, so it can be written as the Global Meteoric Water Line (GMWL). $[4,5,6]$ :

$$
\delta \mathrm{D}, \%=\mathrm{a} \times \delta^{18} \mathrm{O}+\mathrm{d} \%
$$

and for analysis of elevation influence to $\delta^{18} \mathrm{O}$ can be obtained from plotting graph of $\delta^{18} \mathrm{O}$ ratio vs elevation, that will allow this linear equation [7];

$$
\begin{aligned}
& \delta^{18} \mathrm{O} \%=\alpha * \text { elevation }-\beta \\
& \mathrm{E}=\mathrm{c} * \delta^{18} \mathrm{O} \% \mathrm{~d} \% \mathrm{~d}, \ldots .
\end{aligned}
$$

or

Based on equation (8), if we have the ratio of $\delta 180$ groundwater sample data, we can estimate the elevation of origin or groundwater recharge area.

This study used 5 (five) rainwater samples that have taken from Sindoro volcanoes with different significant elevation. Each location is taken samples for three times at significant different of rainfall i.e at January, February, and March 2017, so that the different effects of rainfall on the isotopic compositions are easily observed. In order to use rainfall data from Meteorology, Climatology and Geophysics Agency (MCGA), the location of rainwater sampling is strived to be within the coverage radius of BMKG nearest rainfall monitoring station. Some of the factors considered in water sampling include:

a) The sampling location has significant elevation differences so that the effect of elevation differences on the isotopic composition is easily observed,

b) The sampling location is still within the radius of the coverage area of the rainfall monitoring station so that the rainfall data in MCGA station can be used as secondary data to take into account the effect of rainfall on the isotope composition,

c) The accessibility of the sampling sites so that the rainwater samples can be taken easily, and

d) Time of rainwater sampling is $3 \times$ which conducted in the month where the rainfall has significant difference so that the difference of rainfall effect to the isotope composition is easily observed.

\section{Result and Discussion}

By considering determination of rainwater samples location, then the coordinate data of rainwater samples in Wonosobo are shown in Table 2. The coordinate of rainwater samples is plotted on location map (see Fig. 1). 


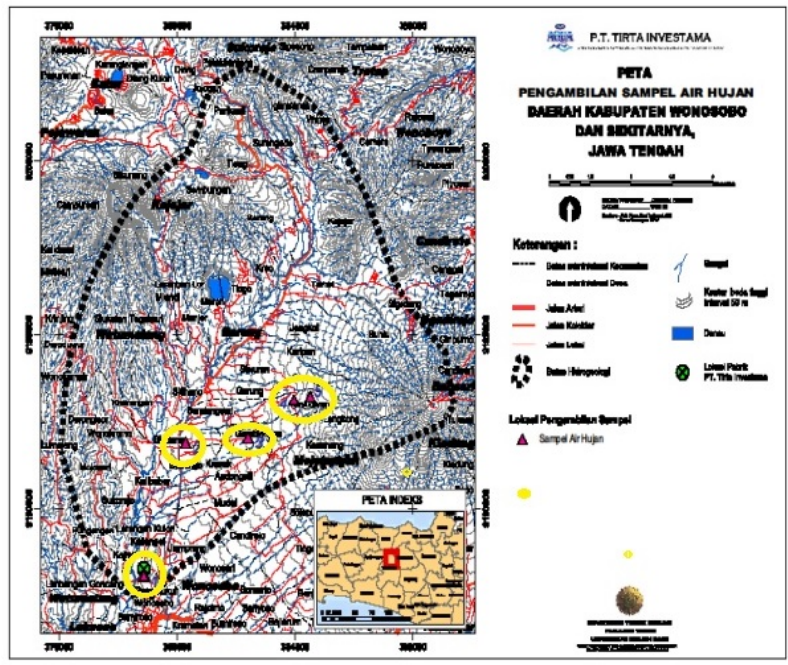

Fig. 1. Location map of rainwater samples

E-1AH is Banaran, Kayugiyang village, Garung, E-2AH is Dsn. Kalilang, Kayugiyang village, Garung. E-3AH is Glebengan village, Garung, E-4AH is Blederan village, Mojo Tengah, and E-5AH is Kejiwan village.

Table 2. Coordinates of rainwater samples

\begin{tabular}{ccc}
\hline code & \multicolumn{2}{c}{ Latitude } \\
\cline { 2 - 3 } & LS & B T \\
\hline$(2)$ & $(4)$ & $(5)$ \\
\hline E-1AH & $07^{0} 17.978^{\prime \prime}$ & $109^{0} 57.328^{\prime \prime}$ \\
\hline E-2AH & $07^{0} 17.978^{\prime \prime}$ & $109^{0} 56.987^{\prime \prime}$ \\
\hline E-3AH & $07^{0} 18.630^{\prime \prime}$ & $109^{0} 56.086^{\prime \prime}$ \\
\hline E-4AH & $07^{0} 18.727^{\prime \prime}$ & $109^{0} 54.823 ”$ \\
\hline E-5AH & $07^{0} 20.931 ”$ & $109^{0} 54.019 ”$ \\
\hline
\end{tabular}

Rainwater samples are collected in $120 \mathrm{ml}$ bottle (Fig. 2) then analyzed with Liquid Water Stable Isotope Analyzer (LWSIA-LGR DLT-100).

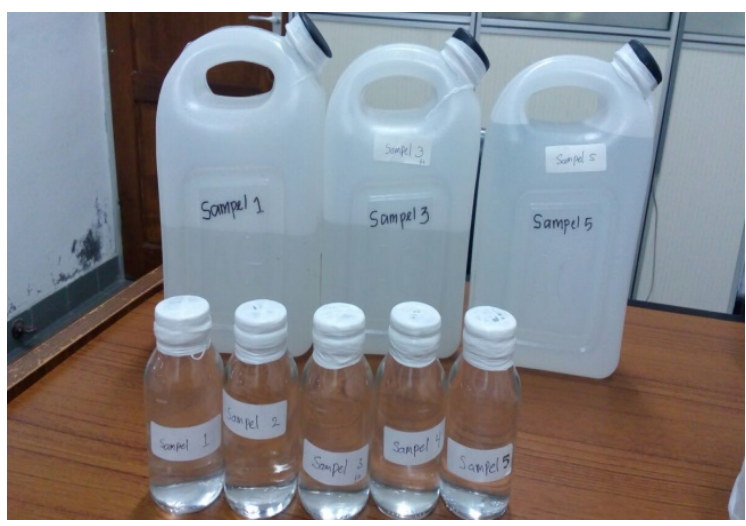

Fig. 2. Rainwater samples

The calculation of rainwater isotope ratio relative to SMOW is shown in Table 3 and Table 4.
Due to the monthly rainfall is fluctuating and theoretically, this phenomenon affects the isotope ratios of $\delta \mathrm{D}$ and $\delta^{18} \mathrm{O}$. This is evident from the measurement of the ratios of rainwater isotopes taken at the same elevation but sampling in different months (see Table 3 and Table 4). Theoretically, the higher the rainfall the more depleted of isotope ratio of $\delta \mathrm{D}$ and $\delta^{18} \mathrm{O}$ and vice versa the lower the rainfall the more enriched of isotope ratio of $\delta \mathrm{D}$ and $\delta^{18} \mathrm{O}$. Therefore, the isotope ratios of $\delta \mathrm{D}$ and $\delta^{18} \mathrm{O}$ of water samples in Table 3 and Table 4 are then compared using Eq. 4 and Eq. 5 in order to know the effect of the average monthly rainfall value in each elevation.

Table 3. Isotope ratio of $\delta \mathrm{D}$ in rainwater samples relative to SMOW

\begin{tabular}{cccccc}
\hline \multirow{2}{*}{ No } & \multirow{2}{*}{$\begin{array}{c}\text { Location } \\
\text { code }\end{array}$} & $\begin{array}{c}\text { Elevation, } \\
\text { m.asl }\end{array}$ & $\begin{array}{c}\text { Jan } \\
\mathbf{2 0 1 7}\end{array}$ & $\begin{array}{c}\text { Feb } \\
\mathbf{2 0 1 7}\end{array}$ & $\begin{array}{c}\text { Mar } \\
\mathbf{2 0 1 7}\end{array}$ \\
\hline$(1)$ & $(2)$ & $(3)$ & $(4)$ & $(5)$ & $(6)$ \\
\hline 1 & E-1AH & 1474 & -51.88 & -46.76 & -49.85 \\
2 & E-2AH & 1365 & -49.99 & -45.81 & -47.85 \\
3 & E-3AH & 1126 & -46.05 & -41.26 & -43.12 \\
4 & E-4AH & 935 & -41.69 & -38.73 & -42.18 \\
5 & E-5AH & 744 & -40.75 & -31.12 & -40.08 \\
\hline
\end{tabular}

Source: primary data

Table 4. Isotope ratio of $\delta^{18} \mathrm{O}$ in rainwater samples relative to SMOW

\begin{tabular}{cccccc}
\hline \multirow{2}{*}{ No } & \multirow{2}{*}{$\begin{array}{c}\text { Location } \\
\text { code }\end{array}$} & \multirow{2}{*}{$\begin{array}{c}\text { Elevation, } \\
\text { m.asl }\end{array}$} & $\begin{array}{c}\text { Jan } \\
\mathbf{2 0 1 7}\end{array}$ & $\begin{array}{c}\text { Feb } \\
\mathbf{2 0 1 7}\end{array}$ & $\begin{array}{c}\text { Mar } \\
\mathbf{2 0 1 7}\end{array}$ \\
\hline$(1)$ & $(2)$ & $(3)$ & $(4)$ & $(5)$ & $(6)$ \\
\hline 1 & E-1AH & 1474 & -8.91 & -6.52 & -8.12 \\
2 & E-2AH & 1365 & -8.69 & -6.24 & -8.01 \\
3 & E-3AH & 1126 & -8.15 & -6.01 & -7.12 \\
4 & E-4AH & 935 & -7.79 & -5.71 & -6.83 \\
5 & E-5AH & 744 & -7.41 & -5.41 & -6.29 \\
\hline
\end{tabular}

Source: primary data

In this study, the rainfall data at the sampling site is taken from the result of rainfall record in 2005-2009 at 26-B Monitoring Station, 24-A Monitoring Station, and 24-F Monitoring Station located in Kali Serayu River Basin and surrounding. Because rainwater sampling in each location is done in January, February, and March 2017, the rainfall data used is rainfall data in January, February, and March which is sterilized from MCGA rainfall data in 2005-2009, as presented in Table 5.

From Table 3 and Table 4 shows that the value of precipitation or rainfall affects the isotopic ratios contained in rainwater. At the same location, the higher rainfall will be the greater dilution of the deuterium and oxygen-18 heavy isotopes in the rain, thus the ratio of $\delta \mathrm{D}$ and $\delta^{18} \mathrm{O}$ is also getting depleted. For example, in Banaran Village, Kayugiyang Village, Garung District $(\mathrm{E}-1 \mathrm{AH})$ which is the highest rainwater sampling 
location (1474 m.asl), the highest rainfall occurred in January, i.e. $514.20 \mathrm{~mm}$ per month, has an isotope ratio in the depleted rain water, i.e. $\delta \mathrm{D}=-51.88 \%$ and $\delta^{18} \mathrm{O}$ $=-8.91 \%$, whereas the lowest rainfall occurred in February, i.e. $480.20 \mathrm{~mm}$ per month; at the same elevation (1474 m.asl) the ratio of isotopes in rainwater is more enriched, i.e. $\delta \mathrm{D}=-46.76 \%$ and $\delta^{18} \mathrm{O}=-6.52$ $\%$. The same phenomenon also occurs at other sampling sites, the higher the rainfall the more depleted the isotope ratios. Therefore, to obtain a representative isotope ratios value representing the actual value at a certain elevation, the effect of rainfall variation on the isotope ratios must be calculated using Equations 4 and 5. The results of the calculated values of the isotope ratios of $\delta \mathrm{D}$ and $\delta^{18} \mathrm{O}$ in rainwater samples taking into account the variations in rainfall during sampling are presented in Table 6.

Table 5. Average monthly rainfall data in 5 sampling sites.

\begin{tabular}{|c|c|c|c|c|}
\hline \multirow{2}{*}{$\begin{array}{c}\text { Location } \\
\text { code }\end{array}$} & \multirow{2}{*}{$\begin{array}{c}\text { Elevation } \\
\text { (m.asl) }\end{array}$} & \multicolumn{3}{|c|}{ rainfall $\left(P_{i}\right), \mathrm{mm}$} \\
\hline & & Jan'17 & Feb'17 & Mar'17 \\
\hline$(2)$ & (3) & (4) & $(5)$ & (6) \\
\hline E-1AH & 1474 & \multirow{2}{*}{514.20} & \multirow{2}{*}{480.20} & \multirow{2}{*}{485.40} \\
\hline E-2AH & 1365 & & & \\
\hline E-3AH & 1126 & \multirow{2}{*}{456.80} & \multirow{2}{*}{408.20} & \multirow{2}{*}{474.40} \\
\hline E-4AH & 935 & & & \\
\hline E-5AH & 744 & 598.40 & 643.20 & 594.00 \\
\hline
\end{tabular}

Table 6. Isotope ratio data of rainwater samples as the funtion of elevation

\begin{tabular}{ccccc}
\hline & \multirow{2}{*}{ No. $\begin{array}{c}\text { Lotion } \\
\text { Code }\end{array}$} & $\begin{array}{c}\text { Elevation } \\
\text { (m.asl) }\end{array}$ & \multicolumn{2}{c}{$\begin{array}{c}\text { Average isotope } \\
\text { compotition }\end{array}$} \\
\cline { 4 - 5 } & & & $\boldsymbol{\delta D}, \mathbf{\% o}$ & $\boldsymbol{\delta}^{\mathbf{1 8}} \mathbf{0 , \% o}$ \\
\hline$(1)$ & $(2)$ & $(3)$ & $(4)$ & $(5)$ \\
\hline 1 & E-1AH & 1474 & -49.55274 & -7.8753 \\
2 & E-2AH & 1365 & -47.93234 & -7.6719 \\
3 & E-3AH & 1126 & -43.55726 & -7.1329 \\
4 & E-4AH & 935 & -40.96462 & -6.8160 \\
5 & E-5AH & 744 & -37.15668 & -6.3467 \\
\hline
\end{tabular}

Based on the data of deuterium and oxygen-18 isotope ratios in Table 6. a graph of $\delta^{18} \mathrm{O}$ versus $\delta \mathrm{D}$ was created to obtain the Local Meteoric Water Line (LMWL) curve in Wonosobo District. Fig. 3 shows the LMWL curves of Wonosobo District and the Global Meteoric Water Line (GMWL) as a comparison.

LMWL Wonosobo equation can be obtained with the least square regression method form data are shown in Figure 3. The LMWL Wonosobo equation is:

$$
\delta \mathrm{D}, \% \text { o }=8.102 * \delta^{18} \mathrm{O}+14.21 \%
$$

with determination coefficient $\mathrm{R}^{2}=0.998$

The LMWL-Wonosobo equation obtained in this study is not much different with Dansgaard research [8], the global meteoric water line (GMWL) that follows Eq. 10 .

$$
\delta \mathrm{D}, \%=8 \delta^{18} \mathrm{O}+10 \%
$$

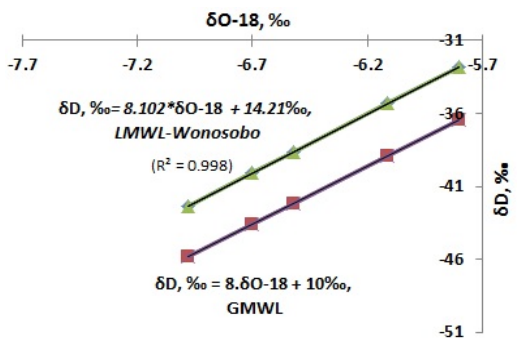

Fig. 3. LMWL Wonosobo and GMWL curve

The difference between LMWL and GMWL is caused by geographical and regional conditions. Geographical differences will have the different temperature, humidity, elevation, and rainfall. The GMWL equation was obtained from the analysis of the average isotope composition of the rainwater samples from various countries in the world that have different climates, whereas LMWL-Wonosobo was obtained based on analysis of isotope rainwater sampling composition taken from the Western Slope of Gunungapi Sundoro located in the tropical area.

The rainwater sample was taken in Kejiwan Hamlet at the lowest elevation (E-5AH; $744 \mathrm{~m} . \mathrm{asl})$ from 5 sampling sites has a more enriched isotope ratios, i.e. $\delta \mathrm{D}$ $=-37.15668 \%$ and $\delta^{18} \mathrm{O}=-6.3467 \%$; and on the other hand the rainwater at a high elevation in Banaran Hamlet, Kayugiyang Village, Garung Sub-district (E1AH: $1474 \mathrm{~m}$.asl) has more depleted isotope ratios, $\delta \mathrm{D}=$ $-49.55274 \%$ and $\delta^{18} \mathrm{O}=-7.8753 \%$ (Table 6);

The results of this measurement correspond to the theory that the higher elevation the depleted isotope ratio of $\delta \mathrm{D}$ and $\delta^{18} \mathrm{O}$ and vice versa. If the data in Table 6 is made a graph of the isotope ratio $\delta^{18} \mathrm{O}$ as an elevation function $(\mathrm{E})$, then the graph will be obtained as shown in Figure 4.

Determining of the isotope ratio $\delta \mathrm{D}$ to the water sample as an elevation function is calculated by entering the value $\delta^{18} \mathrm{O}$ into the LMWL-Wonosobo equation. Thus the $\delta \mathrm{D}$ and $\delta^{18} \mathrm{O}$ isotope composition of the rainwater at each coordinate point located along the LMWL-Wonosobo line carries the elevation information of the rainwater fall location. If the isotopic composition of a water sample taken from the springs and coordinate wells coincides or close to the LMWL line then it is estimated that the water samples are mostly derived from meteoric water (rainwater) [9]. Furthermore, in this study Equations 9, 11 and 12 will be used as a reference in determining the origin of groundwater samples.

The LMWL was based upon a weighted regression using only rain samples. The weighted LMWL is therefore recommended as a more appropriate hydrological input function. We use the weighted LMWL in the following section to approximate the input or source water composition in various reservoirs by regression to their intersection point with the LMWL [10]. 


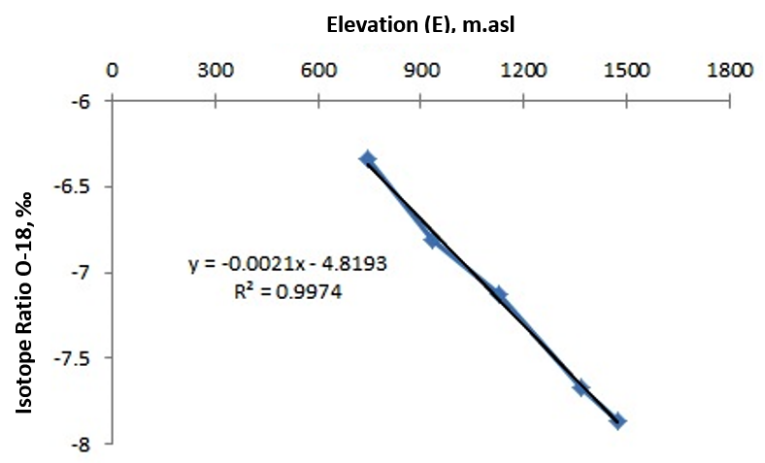

Fig. 4. Elevation versus isotope ratio of $\delta^{18} \mathrm{O}$ in rainwater sample

The higher the elevation, the isotope ratio of $\delta^{18} \mathrm{O}$ in rainwater is increasingly depleted (Fig. 4), following the following equation:

$$
\delta^{18} \mathrm{O} \% \text { o }=-0.0021 * \text { Elevation }-4.8193 \% \text {, }
$$

With determination coefficient, $\mathrm{R}^{2}=0.9974$

or, the equation also can be written as follow:

$$
\mathrm{E}=-476.190 * \delta^{18} \mathrm{O} \% \text { o }-2294.9047 \% \text {, ..... (12) }
$$

Based on equation (12), if we have the ratio of $\delta^{18} \mathrm{O}$ groundwater sample data, we can estimate the elevation of origin or groundwater recharge area. For example, PT. Tirta Investama has Mangli springwater in 720 m.asl which has an isotope ratio $\delta^{18} \mathrm{O}-7.75 \pm 0.2 \%$, with input it to equation 12 , the original groundwater elevation as follow:

E Mangli springwater $=-476.190 *(-7.75 \pm 0.2) \%$ 2294.9047\%

$\mathrm{E}$ Mangli springwater $=1395.5 \mathrm{~m}$. asl until

$\mathrm{E}_{\text {Mangli springwater }}=1509.8 \mathrm{~m} . \mathrm{as} 1$
The equation of LMWL Wonosobo is $\delta \mathrm{D}, \%=8.102 *$ $\delta^{18} \mathrm{O}+14.21 \%$ and the estimation of PT Tirta Investama Danone Aqua spring elevation based on elevation equation to the ratio of $\delta{ }^{18} \mathrm{O}$ is 1395.5 m.asl -1509.8 m.asl.

\section{Acknowledgments}

We would like to thank PT. Tirta Investama Danone Aqua for supporting this research activity, and to the student for assisting of water sample collection. The manuscript was improved by the critical comments of two anonymous reviewers.

\section{References}

1. N. Salonga, World Geothermal Congress (2015)

2. J. Crawford, C.E. Hughes, S. Lykoudis. J of Hydrology 519,2331-2340 (2014)

3. IAEA/WMO. Global Network of Isotopes in Precipitation (2013)

4. N. Kresic and Z. Stevanovic, ButterworthHeinemann, 573, ISBN 978-1-85617-502-9 (2010)

5. I. Clark and P. Fritz, Lewis Publishers, Boca Raton (1997)

6. H. Craig. The Standart for reporting concentrations of deuterium and oxygen-18 in natural water. Science, 133, 1833-1934, (1961a)

7. A.B. Wijatna, H. Hendrayana, et all, Report on Hydro-isotope Study in PT Tirta Investama Danone Aqua Plant Wonosobo (2017)

8. W. Dansgaard, Phys.Lab.11. H. C. Orsted Institure (1964)

9. J.I. Drever, The Geochemistry of Natural Water, Pearson Edu.Canada, (1988)

10. T. Baer, S.L. Barbour, J.J. Gibson., J of Hydrology 541, 1155 - 1164 (2016)

\section{Conclusion}

